\title{
Institutional Empowerment Policy of the Municipal Disaster Management Board in Padang City, West Sumatera Province, Indonesia
}

\author{
Khairul; Hartuti Purnaweni; Sri Suwitri \\ Public Administration Doctoral Program, Faculty of Social and Political Science \\ Diponegoro University \\ Semarnag, Indonesia \\ (Office Email: Prodidap@gmail.com)
}

\begin{abstract}
In Indonesia, awareness of considering disaster risks in each developmental process should be made more efficient and effective based on the country's position which is prone to various disasters. This study presented analysis on disaster management in Padang City, West Sumatera Province, Indonesia, by proposing municipal institutional empowerment, with the Municipal Disaster Management Board as the leading independent actor, using Actor Network Theory. Padang Disaster Management Board is now the sub-section of the Fire Department, less empower for being effective in disaster situation. It is recommended that this Municipal Board should be directly under the authority of Padang Mayor, in close cooperation with Army/Police units and disaster experts.
\end{abstract}

Keywords-Disaster Management; Padang; Municipal Disaster Board; Network Theory

\section{INTRODUCTION}

Indonesia is geologically located in severe risk disaster area because of its geodynamic position at the intersection of active tectonic shelves, besides its very long coastline, suitable for "disaster laboratory" (Maarif, 2012). The United Nations Development Programme Bureau for Crisis Prevention and Recovery (2014) reported the destructive effect of natural hazards, in which especially developing countries, including Indonesia, face great risk from disasters because of the rapid and uncontrolled growth of its cities. These cities are vulnerable to natural hazards because of higher densities of population and urban sprawl (Chian, 2016; Aydin et al, 2015). Indeed there was a huge tsunami hit Aceh Province in 2004, causing around 250.000 casualties and lots of damages because of lack of disaster resilience. According to Maarif (2012), other huge disaster recorded are among others: Yogya and Central Java (2006), West Sumatera (2007), and Merapi eruption (2010). Therefore, there is a need for effective, comprehensive, integrated and sustainable disaster risk reduction. The Indonesian government has responded this phenomenon by stipulating Law No. 24/2007 on Disaster Management. The law directs local governments to establish local municipal/regencial boards for disaster management, and according to decentralization principle shared responsibility with the central government for minimizing disaster risks.
This study perform a policy analysis using Actor Network Theory, with an objective analyzing local policy on the establishment of Municipal Disaster Management Board (BPBD) according to Law No. 24/2007, in Padang City, West Sumatera Province. On 12 September 2007 a large megatrust earthquake $(8.5 \mathrm{Mw})$ occurred off the west coast of Sumatera, but the tremors were felt across the island. The most heavily damaged areas were among others the cities of Padang and Bengkulu (Chian, 2016).

According to Sandewi (2013) Actor Network Theory (ANT) was initiated and developed by Bruno Latour, Michel Callon and John Law. They believed that communities do not merely consist of individual humans and norms which regulate them, but also networks. The ANT holds that a scientific invention does not derive from a particular closed individual; it develops through networks, which involve both human and non-human aspects. ANT introduces a concept of network among actors, which does not only focus on social relations among human actors, but also non-human ones, creating a heterogenous network. Actor is the one that acts, not only human, but also technical object. (ISSDR, 2011; Krisna, 2010; Sandewi, 2013)

\section{TheORETICAL FramewORK AND Method}

This study used qualitative descriptive method. Padang was chosen as research location in 2015 , since this city is prone to disaster in terms of earthquake and tsunami, and already established BPBD office. The interviewees were: four members of municipal parliament, two DinkarBP staffs, Kogami (Tsunami Resilience Community), HSNI (Fishermen Association), and three informal society heads. This primary data was completed with a number of related documents and observations. The documents and results of interviews were qualitatively analyzed based on the research framework.

\section{Result AND Discussion}

Disasters that occured in Indonesia, in particular Aceh tsunami in 2004, have moved the government to postulate new regulation by issuing Government Law No. 83/2005 on National Coordination Body for Disaster Management (Bakornas-PB). The House of Representatives then proposed 
Law No. 24/2007 on Disaster Management, which requires the establishment of a new national level body namely National Disaster Management Board (BNPB) to replace the National Coordination of Disaster Management (Bakornas-PB). At the local level, the similar body, Disaster Management Board (BPBD) should also be established to replace the former Field Coordination Unit of Disaster Management (Satkorlak) at provincial level, and Field Unit of Disaster Management (Satlak) at municipal/regencial level.

However, cost allocation for disaster management, from mitigation to rehabilitation and reconstruction stages, does not change after the emergence of BNPB and BPBD. Reserve fund which is mandatory according to the Law Number 24/2007, does not have a clear mechanism yet. Therefore, there is a fundamental problem faced by BPBD Padang City concerning budget allocation for disasters. Disaster-prone area, such as Padang City, has not been supported by a good financial strength, although it has low local income. The present efforts of developing strategy and operation of disaster risk reduction in Padang City is mostly by optimizing the current institutional mechanism and function, as well as encouraging the local government institutions (SKPD) to also allocate disaster fund in their budget.

Law No. 24/2007 stated that the provincial and local government has to erect local institution for disaster management to replace Satkorlak and Satlak. Following this, Padang City then issued Padang Municipal Regulation No. $17 / 2012$ on the Establishment of Organization and Tasks of Local Disaster Management and Fire Fighting Board (DinkarPB), integrating the former Fire Fighting Department and Disaster Management Board into a single institution (SKPD). The DinkarPB is not an independent unit of SKPD but joined with the Fire Fighting Department, consist of only three departments and six sections. At institutional level, the BPBD-Fire Fighting Department integration is subordinate to the Local Secretariat.

This mechanism has raised a fundamental problem. Following Law No. 24/2007, the Minister of Interior Decree No. 46/2008 on Guidelines for Organization and Task of BPBD, and in the BNPB Chief Decree No. 3/2008 on Guidelines for BPBD Establishment require that BPBD has multiple functions, including coordination, command, and operation. The institutional concept of BPBD is a public institution with unique characteristics, leading to institutional problems in the local government. Usually each SKPD only has one function, foe example the Public Works Office for taking care of public works issues.

Such far-reaching functions by DinkarPB might lead to task and function overlapping in the practice of disaster risk reduction, jeopardizing the existing institutionalizations of the local government. BPBD functions is regulated in the Minister of Interior No. 46/2008, Article 3(1): Provincial and Municipal/Regencial BPBDs are under and responsible to Governor or Mayor/Regent. Article 2 requires that Provincial and Municipal/Regencial BPBDs are led by Chief of Agency, which is in ex-officio held by the Municipal/Regencial Secretary. Such double position is not in line with the existing human resources regulations, in which a government position should not be doubled by the same person. Moreover, Head of Padang DinkarPB will find coordination difficulties with other heads of SKPDs, since they are in the same ranks. The same problem should occur if coordination with the Army/Police is needed. Disaster is inherently complex environments, and has the following features: unpredictability, unfamiliarity, speed, urgency, uncertainty, threat (Biswas, 2012; Aydin, 2015).

Analyses on the institutional empowerment is necessary for Padang DinkarPB using Actor Network Theory (ANT) to make the DinkarBD tasks aremore efficient and effective. According to the ANT theory, actors involved in the policy-making process are the followings: initiator (actant) is Padang Municipal Government; the implementor (DinkarPB, Municipal Office of Public Works, Office of Social Affairs, and Army/Police units). The other implementors are state apparatus from village chiefs, district chiefs, to neighborhoods, civil society organization (Kagami, HNSI) and local informal leaders. Beneficiaries of this activity are communities affected by the disaster. Disaster management requires considerations of several stakeholders, and also their interaction (Rivera, 2015; Couto and Latour, 2016).

The Municipal Government of Padang as the initiator (performed by DinkarPB) also acts as an implementor of the policy. Meanwhile, Army/Police units have been widely involved in the policy-making process although they are important actor that coordinate and command during the disaster. Other state apparatus, civil societies, and communities are functioned at the front line of actor network. Furthermore, local leaders are also involved immediately as actors who advices Padang Municipal Government in the policy making for empowering DinkarPB. Municipal House of Representatives also become part of the policy network as focus actor, which evaluate the policy on disaster risk reduction in Padang City.

According to this ANT model, it is necessary to synchronize Law No. 24/2007 with Minister of Interior Decree No. 46/2008 and BNPB Agency Head Decree No. 3/20078 in order to prevent overlapping regulation on Padang DinkarPB. ANT suggests that DinkarPB should no longer become the sub section of the Fire Fighting Department. Instead, it has to become an independent institution, responsible ex-officio to the Mayor of Padang. Whereas, Army/Police units do not only become implementors under the command of DinkarPB during the disaster, but also become part of Supervising Team alongside Disaster Experts Team. Hence, Padang Municipal House of Representatives and Padang Municipal Government have to work together to stipulate a new Local Regulation concerning the Establishment of Organization and Task of the Local Board for Disaster Management in Padang City.

\section{CONCLUSION}

Conclusion to be drawn from the discussion are as follows: a) Law No. 24/2007 on Disaster Management, accompanied by by Minister of Interior Decree No. 46/2008 on Guidelines of Organization and Task of BPBD, and BNPB Head Decree No. $3 / 2008$ on Guidelines of BPBD Establishment require that BPBD has bigger functions than other SKPSs: coordination, command, and also operation/implementation. Therefore, 
DinkarPB position should not be parallel with other SKPDs by giving it direct subordinate position under Padang Mayor; b) Army/Police units are not only act as implementors, but also take part in the supervising team alongside experts and professionals. Disaster management in Padang Municipality should be supported by important elements; and c) Padang House of Representatives and Mayor of Padang work together to issue Municipal Regulation on the Establishment of new organization for disaster management in Padang City as an independent body.

\section{REFERENCES}

[1] Aydin, Can, Cigdem Tarhan, Ahmet Selcuk Ozgur, Vahap Tacim, "Improving Disaster Resilience Using Mobile Based Disaster Management System", 9th International Conference Interdisciplinary in Engineering, INTER-ENG 2015, 8-9 October 2015, Tirgu-Mures, Romania, in Procedia Technology 22 (2016) 382- 390.

[2] Biswas, Bidhan Chandra, and Sabuj Kumar Choudhuri, "Digital Information for Disaster Management of Libraries and Information Centres", Bangladesh Journal of Library and Information Science, Volume 2 Number 1, 2012, p 12-13.

[3] Chian, Siau Chen, "A Complementary Engineering-Based Building Damage Estimation for Earthquakes in Catastrophe Modelling", International Journal of Disaster Risk Science, published online 8March 2016.

[4] Couto, N. and Latour, B. 2013, Bruno Latour dan ANT (Actor Network Theory), published through [http://dc352.4shared.com/doc [accessed on 10 January 2016].
[5] ISSDR. 2011, Global Assessment Report on Disaster Risk Reduction Revealing Risk, Redefiningg Development, Information Press, Oxford, UK.

[6] Krisna. 2010, Mengelola Resiko Bencana di Negara Maritim Indonesia, Lembaga Penelitian dan Pengabdian Kepada Masyarakat ITB (Managing Disaster Risk in Indonesian Maritime Country, Center of Research and Community Devotion of Bandung Institute of Technology)

[7] Lassa, J. A. 2013, Civil Society Roles in Governing Disaster Reduction: Case Study From National and Local Levels in Indonesia, Institute of Resources Governance and Social Change.

[8] Maarif, Syamsul (Head of the National Disaster Management), 2013, public lecture on Disaster Mitigation and Resilience, Post Graduate Program, Diponegoro University.

[9] Rivera, Claudia, Henrik Tehler, and Christine Wamsler, "Fragmentation in Disaster Risk Management Systems: A Barrier for Integrated Planning", International Journal of Disaster Risk Reduction 14 (2015: 445.

[10] Sandewi, A. 2013, "Membuat E-Government Bekerja di Desa: Analisa Network Theory Terhadap System Informasi Desa dan Gerakan Desa Membangun" (Making E-Gov Works: Network Theory Analysis to Rural Information System), Jurnal Mandatory, Vol.10, No.2, 2013.

[11] UNDP, 2014, A Global Report: Reducing Disaster Risk, A Challenge for Development (Report No. 92-1-1126160-0), New York, USA

[12] UU No. 24 Tahun 2007 tentang Pembentukan Badan Nasional Penanggulangan Bencana (Law No. 24/2007 on the Establishment of National Agency for Disaster Management)

[13] Peraturan Menteri Dalam Negeri No. 46 Tahun 2008 tentang Pedoman Pembentukan Badan Penanggulangan Bencana Daerah. (Minister of Interior Decree No. 46/2008 on Guidelines for the Establishment of Local Agency for Disaster Management)

[14] Peraturan Daerah Kota Padang Tentang Pembentukan Organisasi dan Tata Kerja Badan Penanggulangan Bencana Daerah dan Pemadam Kebakaran (Padang Municipal Regulation on the Establishment of Organization and Tasks of Local Agency for Disaster Management). 